\title{
The research on educational environment of institution of higher education involving experts: results and analysis
}

\author{
Mariia Bratko*, and Liudmyla Khoruzha \\ Borys Grinchenko Kyiv University, 18/2 Bulvarno-Kudriavska Str., Kyiv, 04053, Ukraine
}

\begin{abstract}
Based on the analysis of scientific resources, the role of educational environment in personal building, development and education is actualized. It is stated that educational environment is one of the most essential factors of those processes. The author's definitions of notions "educational environment", "educational environment of institution of higher education" are given. The authors advocate the point that educational environment is a system of facilities for personal education. It is emphasized that the environmental approach in education is changing accents in teaching which is aimed at creating and developing educational environment, which has to meet educational needs of a student. The author's technique of evaluating the state of educational environment of institution of higher education is grounded and approved, the rating scale of this technique is introduced. The technique suggests making expert evaluation of educational environment of institution of higher education according to qualitative (modality) and quantitative (professional breadth, professional saturation, sociocultural intensity, congruence, openness, mobility, informativeness) parameters. The typology of educational environment of institution of higher education is presented (innovative-professional, formal-professional, pragmatically-oriented, formal general cultural educational environment). The analysis and interpretation of the results obtained from the experiment at University College of Borys Grinchenko Kyiv University are given. The evaluation of educational environment of the college has been made by three groups of experts, which have included students, teachers and parents. Despite the fact that evaluation by different groups of experts are similar, it is revealed that it has essential differences, which has been proved with appropriate statistical methods. It is determined that the substantiation of the whole monitoring system of educational environment of institution of higher education and corresponding diagnostic tools has great potential.
\end{abstract}

\section{Introduction}

One of the most significant factors of the quality of education due to its specifics is educational environment of institution of higher education. Interest in researching it as a component of integral social and living environment of an individual has been growing for the last few decades. At the same time the paradigm of educational environment in personal building and development has changed from the necessary condition to the active contributor that must be created and realized in order to provide high-quality education. The scientific discourse presents different views on the phenomenon of educational environment which is considered as a part of sociocultural space (N. Krylova [1]); a sociocultural system (V. Kozyriev [2]); a system of impacts and factors of personal developvent (V. Yasvin [3]); a complex of opportunities for personal learning and developing (S. Deryabo [4]); a system of key factors that determine personal education and development (V. Lebedeva [5]); a complex of human practices and material systems (T. Warger [6]); a complex of conditions in which instruction takes place and which influence students' performance and relationships
(B. Fraser [7]); a product of a mutual activity of subjects of education (V. Slobodchikov [8]); a complex of facilities for personal education (M. Bratko [9]). We prefer to regard educational environment as a field of opportunities for personality. If conditions characterize 'space', environment is characterized by the notion 'opportunities', i.e. space becomes environment when conditions become opportunities. English-speaking publications extensively demonstrate the results of the study on the impact of educational environment on personality, which researchers interpret as educational environment (J. Salmi [10], S. Cotterill [11]); educational climate (R. Hiemstra [12]); academic environment (A. Lizzio [13]), study/learning environment (I. Abulrub [14], R. Moos [15], T. Wagner [6], B. Fraser [7]). The analysis of the resource base enables to state the development of the environmental approach in education that provides the subject of management with techniques and technologies of using educational environment for personal development and self-development, ensuring the quality of education. To achieve the objective of our research we appeal to approaches to examination, diagnostics and evaluation of educational environment including

\footnotetext{
* Corresponding author: m.bratko@kubg.edu.ua
} 
educational environment of institution of higher education presented in works of S. Deryabo [4], R. Moos [15], V. Rubtsov [16], B. Fraser [7], V. Yasvin, S. Rybinskai [17], which has become the theoretical basis for developing the author's approach to evaluation of educational environment of institution of higher education. Monitoring the state of educational environment of institution of higher education may turn into a significant component of the internal system of ensuring the quality of education and its results may serve to make good managerial decisions.

\section{The objective of research}

The purpose of our research paper is substantiation and approval of the author's technique of evaluation of a current state of educational environment of institution of higher education by the example of University College of Borys Grinchenko Kyiv University according to qualitative and quantitative parameters in order to take managerial decisions concerning its development.

\section{Research methodology}

The purpose of research has made us use the complex of the relevant methods: scientific literature analysis in order to establish the state of the problem development, the definition of the categorical and conceptual apparatus of investigation; synthesis, generalization, systematization for theoretical substantiation and practical development of approaches to diagnostics of the current state of educational environment of institution of higher education; empirical: expert evaluation, vector modelling; mathematical and statistical methods (MannWhitney U-test, Kolmogorov-Smirnov test, Friedman test) to assess the experimental work results.

\section{Results and discussion}

The analysis of the phenomenon of environment, the thesaurus of environmental approach in education, scientific resources dealing with issues about examining educational environment as a factor of personal development and the author's point presented in our previous publications [18] enable to determine the content of fundamental notions of the research. On basis of methodology of the system and environmental approaches, it is defined that the educational environment is a multilevel system of conditions / circumstances / factors / opportunities that provides optimal parameters of the educational activity of certain educational individual in all aspects - target, content, process, result, resource. The educational environment is characterized by: systematic, integrity, unity, emergence, variability, organization, structural, plasticity, communicativeness, eventfulness, configurability, saturation, vectority, sphericity, openness, dialog / polychology, organization, stability, adaptability, functionality ability for development and self-development.The educational environment of a higher educational institution is an integrity that encompasses a set of conditions, impacts, opportunities for vocational training, personal development and socialization of the future specialist. The component structure (personal, axiologicalsemantic, information-content, organizational-active, spatial and substantive components) and functions (polystructural educational in the unity of educationalprofessional, educational-socializing, educationalcultural functions and personalized-developing function) of the educational environment of the university college have been determined as well. On the whole, realization of the environmental approach in higher education, professional training takes into account guaranteeing quality education by means of mediation of educational environment of an institution. The environmental approach includes increase in activities directed at designing, modeling and creating educational environment that have to meet educational needs of a student efficiently.

Analyzed approaches to evaluation of activities of educational institutions, effectiveness of educational process, quality of educational environment (L. Vashchenko [19], S. Deryabo [4], V. Yasvin [20] and ets.) enable to define the main qualitative and quantitative parameters of evaluation of educational environment of institution of higher education. As a rule, in researches of environment of institutions of secondary education presence or absence of conditions and opportunities for development of activity or inactivity of the subject of education and their personal freedom is taken as a criterion indicator of modality. In our study we take into consideration educational environment of institution of higher education. Therefore, the qualitative parameter (modality) of educational environment of institution of higher education is adjusted with its main functions (polystructural educational one which consists of educational-professional, educational-socializing, educational-cultural and personalized-developing functions) and is characterized from the typological point of view. Defining the type of educational environment of institution of higher education, the degree of its orientation to profession, socializing, inculturation, general personal development is taken into account. Such an approach enables to determine the types of educational environment of institution of higher education considering existing approaches to typology of educational environment: innovative-professional (modern, filled with professional content and activities with well-developed practice-oriented component of educational process, prioritizing development of professional competences of future specialists, creative thinking, $21^{\text {st }}$ century skills, open-mindness and adaptability to sociocultural context); formalprofessional (filled with professional context but preference is given to theoretical instruction, practiceoriented component of educational process is underdeveloped, characterized by low saturation of socio-humanitarian life of an educational institution); pragmatically-oriented (environment aimed at meeting individual educational needs of students and their parents concerning organization of professional training and socio-humanitarian life of an educational institution); formal general cultural (first of all aimed at general cultural and personal development of students, occasionally harmful to professional training). Researchers of educational environment suggest different lists of its quantitative parameters. The most 
frequently mentioned ones are the following: breadth, intensity, awareness, resilience, community, dominance, social activity, mobility, information, formality, emotionality, orientation, structure, coherence, professionalism, security. We have made a list of characteristics for evaluation of educational environment of institution of higher education taking into consideration researchers' discoveries, our own position, peculiarities of an institution of higher education as an institution that provides professional training. Hence, in our case, the quantitative parameters feature filling the environment of an institution of higher education with various factors of professional training, namely: professional breadth (quantity and quality of subjects and objects, processes, phenomena with professional orientation), professional saturation (the degree of saturation with professional resources, technologies, contacts with people in profession, educational projects, clubs and studios), sociocultural intensity (the degree of saturation with conditions, impacts, opportunities for personal socializing and inculturation), congruence (the degree of adjustment of functioning all components), openness (demonstrates the degree of social orientation and involvement of educational environment in the surrounding world, availability of ways for social partnership to perform multiaspect educational function of educational environment), mobility (the degree of ability of educational environment to meet demands of outside context concerning the content, forms, methods and technologies of professional training), informativeness (features the degree of saturation and availability of information resources).

The approbation of determined criteria for evaluation of educational environment of institution of higher education by means of the expert method was carried out at University College of Borys Grinchenko Kyiv University (further on College) during 2012-2018. This publication presents the results of the research conducted in 2018. The participants of educational process students, teachers, parents - performed a function of experts.

Expert groups were offered to evaluate the types of educational environment (its modality) according to 5point scale, where 5 points corresponds to the highest level of the certain type manifestation and 1 point - to the lowest one. It is important to remember that there cannot be 'pure' type of educational environment. Any educational environment of an educational institution possesses characteristics of every type. However, characteristics of a peculiar type can dominate, thus they determine general orientation of environment.

Evaluation of educational environment of institution of higher education according to modality was made by 294 students $(22,7 \%$ out of overall number of the student body at the time of the experiment, all courses and majors which are provided at College were represented), 83 teachers $(49 \%$ out of general number of pedagogical staff) with different work experience in institutions of higher education (10 people with work experience of less than 5 years; 19 people - from 5 to 10 years; 23 people from 10 to 20 years; 31 people - from 20 to 30 years), 250 parents. A special google-form was created to carry out the survey. Identification of nature of received results and their verification were made by means of statistical methods. All calculations were made by means of digital tables Excel, statistical package SPSS [21].

Generalized results of evaluation by experts (students, teachers, parents) of manifestation of types of educational environment (modality) at University College in 2018 are presented in Table 1.

Table 1. The results of evaluation of manifestation of types of educational environment by experts at College, 2018.

\begin{tabular}{|c|c|c|c|c|}
\hline \multirow[b]{2}{*}{ No } & \multirow[b]{2}{*}{ Type of educational environment } & \multicolumn{3}{|c|}{ Expert group } \\
\hline & & 总 & $\frac{\mathscr{0}}{\stackrel{d}{ \pm}}$ & \\
\hline 1 & innovative-professional & 4,22 & 4,13 & 4,14 \\
\hline 2 & formal-professional & 3,31 & 3,34 & 3,22 \\
\hline 3 & pragmatically-oriented & 3,72 & 3,51 & 3,71 \\
\hline 4 & formal general cultural & 3,71 & 3,23 & 3,22 \\
\hline
\end{tabular}

Generalized results demonstrate that the highest points by each group of experts were given to innovativeprofessional environment. However, other types of environment have also a high degree of manifestation. It must be stated that evaluation of parent experts and teacher experts are almost identical in all types. Evaluation of innovative-professional and pragmaticallyoriented types of environment is similar by all types of experts. Points by student experts are significantly different from those by other experts concerning the formal general cultural type of environment. In comments students wrote that they were excessively involved in different entertaining events and concerts and they didn't always understand their connection with the content and goals of professional training. The answers of experts show that educational environment of College corresponds to its aim - providing professional training. In our opinion, it is a bit advance evaluation. In future it is necessary to enhance opportunities for students to obtain professional knowledge and skills at College. We are going to demonstrate approaches to evaluation of reliability of received results by means of statistical methods by the example of the group of student experts. The qualitative and quantitative composition of the group of student experts (according to specialty) and the results of evaluation by them (average indicators in every specialty) of types of educational environment at University College are presented in Table 2 . Kolmogorov-Smirnov test has shown that students' evaluation data are not arranged appropriately, therefore for their comparison we apply non-parametric tests. Since they were dependent groups, the same students evaluated educational environment according to four types. Table 3 and Table 4 show the comparative results of evaluation of types of educational environment of University College by student experts and statistics according to Friedman test. As we see, a posteriori knowledge of statistics $\chi^{2}$ equals 156,721, its significance is less than 0,05 , so the differences between 4 lines of points are considerable. 
Table 2. The results of evaluation of manifestation of types of educational environment at College by student experts, 2018 .

\begin{tabular}{|c|c|c|c|c|c|c|}
\hline \multirow[b]{2}{*}{ No } & \multirow[b]{2}{*}{ Specialty } & \multirow{2}{*}{ 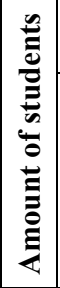 } & \multicolumn{4}{|c|}{$\begin{array}{c}\text { Type of educational } \\
\text { environment }\end{array}$} \\
\hline & & & 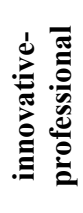 & 立 & 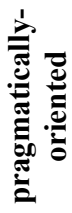 & 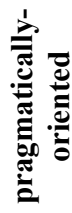 \\
\hline 1 & journalism & 33 & 4,15 & 3,18 & 3,48 & 3,52 \\
\hline 2 & social work & 11 & 4,00 & 2,55 & 3,36 & 3,64 \\
\hline 3 & design & 22 & 3,59 & 3,41 & 3,41 & 3,91 \\
\hline 4 & choreography & 5 & 4,20 & 3,80 & 3,60 & 3,40 \\
\hline 5 & science of law & 8 & 4,13 & 3,25 & 3,25 & 3,75 \\
\hline 6 & $\begin{array}{l}\text { secondary education } \\
(\text { music) }\end{array}$ & 14 & 3,71 & 3,00 & 3,50 & 3,36 \\
\hline 7 & $\begin{array}{l}\text { information, library and } \\
\text { archives }\end{array}$ & 23 & 4,35 & 3,26 & 4,00 & 3,83 \\
\hline 8 & primary education & 70 & 4,43 & 3,33 & 3,87 & 4,01 \\
\hline 9 & pre-school education & 27 & 4,44 & 3,67 & 3,85 & 3,78 \\
\hline 10 & $\begin{array}{l}\text { Secondary education } \\
\text { (arts) }\end{array}$ & 16 & 4,00 & 3,31 & 4,06 & 3,19 \\
\hline 11 & finances & 24 & 4,29 & 3,50 & 3,83 & 3,67 \\
\hline 12 & $\begin{array}{l}\text { secondary education } \\
\text { (physical education) }\end{array}$ & 12 & 4,58 & 3,17 & 3,75 & 3,58 \\
\hline 13 & management & 29 & 4,28 & 3,28 & 3,62 & 3,55 \\
\hline 14 & total & 294 & 4,22 & 3,31 & 3,72 & 3,71 \\
\hline
\end{tabular}

Table 3. The comparative results of evaluation of types of environment at College by student experts (Friedman test), 2018.

\begin{tabular}{|l|l|c|}
\hline No & Type of educational environment & Average ranks \\
\hline 1 & innovative-professional & 3,09 \\
\hline 2 & formal-professional & 2,02 \\
\hline 3 & pragmatically-oriented & 2,46 \\
\hline 4 & formal general cultural & 2,44 \\
\hline
\end{tabular}

Table 4. Statistics (Friedman test) for student experts.

\begin{tabular}{|l|l|c|}
\hline 1 & $\mathrm{~N}$ & 294 \\
\hline 2 & Chi-Square & 156,721 \\
\hline 3 & df & 3 \\
\hline 4 & Asymp. Sig. & 0,000 \\
\hline
\end{tabular}

Calculations for other groups of experts are made in an analogical way. Table 5 and Table 6 show the comparative results of evaluation of types of educational environment at University College by teacher experts and statistics according to Friedman test. As we see, a posteriori knowledge of statistics $\chi^{2}$ equals 30,172 , its significance is less than 0,05 , so the differences between 4 lines of points are considerable. Table 7 and Table 8 show the comparative results of evaluation of types of educational environment of University College by parent experts and statistics according to Friedman test. As we see, a posteriori knowledge of statistics $\chi^{2}$ equals 183,803 , its significance is less than 0,05 , so the differences between 4 lines of points are considerable.

Expert evaluation of educational environment of College according to the quantitative parameters (professional breadth, professional saturation, sociocultural intensity, congruence, openness, mobility, informativeness) in 2018 was made by three groups of experts consisting of students, teachers and parents of about 50 people in each group. The survey was conducted by means of google-form. General data about the results of evaluation of educational environment of College according to specific characteristics, namely - average value in expert groups according to the quantitative parameters (professional breadth, professional saturation, sociocultural intensity, congruence, openness, mobility, informativeness) is presented in Table 9. The graphic image of the results of evaluation of educational environment of College according to the parameters is presented in Fig. 1.

Table 5. The comparative results of evaluation of types of environment at College by teacher experts (Friedman test), 2018.

\begin{tabular}{|l|l|c|}
\hline No & Type of educational environment & Average ranks \\
\hline 1 & innovative-professional & 3,08 \\
\hline 2 & formal-professional & 2,37 \\
\hline 3 & pragmatically-oriented & 2,37 \\
\hline 4 & formal general cultural & 2,17 \\
\hline
\end{tabular}

Table 6. Statistics (Friedman test) for teacher experts.

\begin{tabular}{|l|l|c|}
\hline 1 & $\mathrm{~N}$ & 83 \\
\hline 2 & Chi-Square & 30,172 \\
\hline 3 & df & 3 \\
\hline 4 & Asymp. Sig. & 0,000 \\
\hline
\end{tabular}

Table 7. The comparative results of evaluation of types of environment of College by parent experts (Friedman test), 2018.

\begin{tabular}{|l|l|c|}
\hline No & Type of educational environment & Average ranks \\
\hline 1 & innovative-professional & 3,18 \\
\hline 2 & formal-professional & 2,10 \\
\hline 3 & pragmatically-oriented & 2,65 \\
\hline 4 & formal general cultural & 2,06 \\
\hline
\end{tabular}

Table 8. Statistics of Friedman test for parent experts.

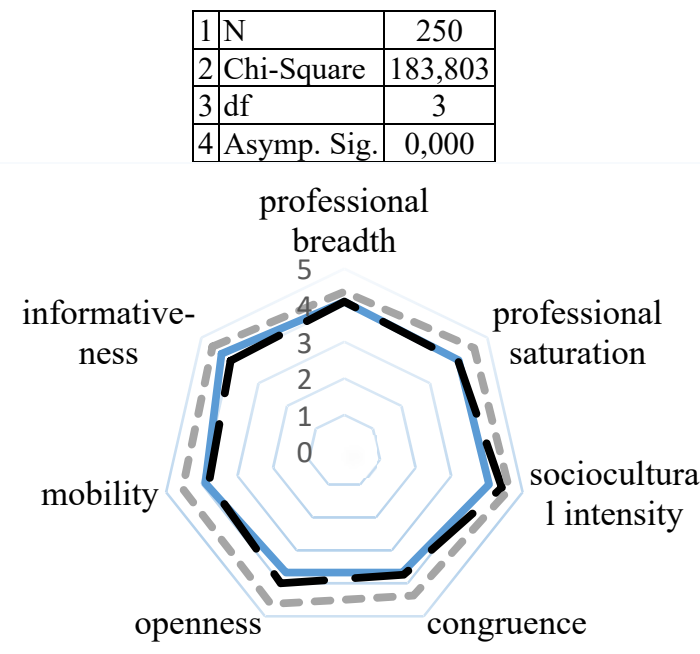

$\longrightarrow$ students - teachers --- parents

Fig. 1 The graphic image of the results of evaluation of educational environment of College according to the parameters, 2018. 
Table 9. The results of evaluation of educational environment of college according to the parameters (average values, in expert groups), 2018.

\begin{tabular}{|c|c|c|c|c|c|}
\hline \multirow[b]{2}{*}{ No } & \multirow[b]{2}{*}{ Parameter } & \multicolumn{3}{|c|}{ Expert group } & \\
\hline & & 苞 & 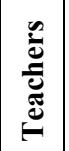 & 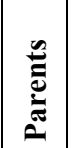 & 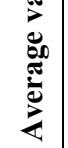 \\
\hline 1 & professional breadth & 4,10 & 4,10 & 4,37 & 4,19 \\
\hline 2 & professional saturation & 4,00 & 3,98 & 4,54 & $4,1^{\prime}$ \\
\hline 3 & sociocultural intensity & 4,06 & 4,42 & 4,63 & 4,37 \\
\hline 4 & congruence & 3,67 & 3,74 & 4,37 & 3,9 \\
\hline 5 & openness & 3,67 & 4,00 & 4,63 & 4,1 \\
\hline 6 & mobility & 3,90 & 3,80 & 4,54 & 4,0 \\
\hline 7 & informativeness & 4,29 & 3,98 & 4,61 & 4,3 \\
\hline
\end{tabular}

Let us analyze obtained results. First of all, we are going to identify how different are points of certain groups of experts in pairs according to Mann-Whitney Utest. Let us present the analysis results and give examples of calculations in Table 10 and 11. The analysis of the calculation results in pair of students - teachers shows that points by students and teachers differ considerably according to the following parameters as sociocultural intensity, informativeness (significance is less than 0,05).

Table 10. The comparison of evaluation of educational environment of College according to the quantitative parameter of Mann-Whitney U-test for 2 expert groups of students and parents, 2018.

\begin{tabular}{|c|c|c|c|c|c|}
\hline No & Parameter & Status & $\mathbf{N}$ & $\begin{array}{c}\text { Mean } \\
\text { rank }\end{array}$ & $\begin{array}{c}\text { Sum of } \\
\text { ranks }\end{array}$ \\
\hline \multirow{3}{*}{1} & \multirow{3}{*}{ professional breadth } & students & 50 & 42,17 & 2108,5 \\
\hline & & parents & 41 & 50,67 & 2077,5 \\
\hline & & Total & 91 & & \\
\hline \multirow{3}{*}{2} & \multirow{3}{*}{$\begin{array}{l}\text { professional } \\
\text { saturation }\end{array}$} & students & 50 & 39,65 & 1982,5 \\
\hline & & parents & 41 & 53,74 & 2203,5 \\
\hline & & Total & 91 & & \\
\hline \multirow{3}{*}{3} & \multirow{3}{*}{$\begin{array}{l}\text { sociocultural } \\
\text { intensity }\end{array}$} & students & 50 & 37,62 & 1881,0 \\
\hline & & parents & 41 & 56,22 & 2305,0 \\
\hline & & Total & 91 & & \\
\hline \multirow{3}{*}{4} & \multirow{3}{*}{ congruence } & students & 50 & 36,93 & 1846,5 \\
\hline & & parents & 41 & 57,06 & 2339,5 \\
\hline & & Total & 91 & & \\
\hline \multirow{3}{*}{5} & \multirow{3}{*}{ openness } & students & 5 & 35,85 & 1792,5 \\
\hline & & parents & 41 & 58,38 & 2393,5 \\
\hline & & Total & 91 & & \\
\hline \multirow{3}{*}{6} & \multirow{3}{*}{ mobility } & students & 50 & 38,12 & 1906,00 \\
\hline & & parents & 41 & 55,61 & 2280,0 \\
\hline & & Total & 91 & & \\
\hline \multirow{3}{*}{7} & \multirow{3}{*}{ informativeness } & students & 50 & 40,97 & 2048,5 \\
\hline & & parents & 41 & 52,13 & 2137,5 \\
\hline & & Total & 91 & & \\
\hline
\end{tabular}

Student experts evaluate informativeness higher $(+0,31)$ than teacher experts do. Teacher experts evaluate sociocultural intensity higher $(+0,36)$ than student experts do. Other parameters do not have significant differences. Evaluation by students and parents differ in all parameters except professional breadth (significance is less than 0,05). In particular, parents evaluate educational environment according to parameters - professional saturation $(+0,54)$, sociocultural intensity $(+0,57)$, congruence $(+0,7)$, openness $(+0,96)$, mobility $(+0,55)$, informativeness $(+0,32)$. Evaluation by teachers and parents differ considerably in all parameters except professional breadth (significance is less than 0,05 ). We should state that parents evaluate educational environment higher than teachers in all parameters. In particular: professional saturation $(+0,56)$, sociocultural intensity $(+0,21)$, congruence $(+0,63)$, openness $(+0,63)$, mobility $(+0,74)$, informativeness $(+0,63)$. On the whole, points by parent experts are higher than those of other experts in every parameter. Although student experts and teacher experts evaluate educational environment differently, their points are very similar. Such results were unexpected. Researches by V. Yasvin [20] show that the highest points are usually given by teacher experts and administration board, the lowest ones - by students, and point by parents are between them. From interviewing parents, it is stated that they idealize the place where their children are studying. Partially, parents explain that by the fact that they took responsibility in choosing an educational institution taking into consideration their children's age and they did not choose the worst one.

Table 11. Statistics of Mann-Whitney U-test for 2 expert groups of students and parents, 2018.

\begin{tabular}{|c|c|c|c|c|c|}
\hline No & Parameter & 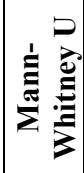 & 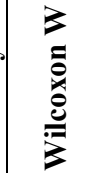 & $\mathbf{Z}$ & 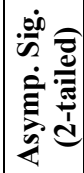 \\
\hline 1 & professional breadth & 833,5 & 2108,5 & $-1,699$ & 0,089 \\
\hline 2 & professional saturation & 707,5 & 1982,5 & $-2,742$ & 0,006 \\
\hline 3 & sociocultural intensity & 606,0 & 1881,0 & $-3,715$ & 0,000 \\
\hline 4 & congruence & 571,5 & 1846,5 & $-3,890$ & 0,000 \\
\hline 5 & openness & 517,5 & 1792,5 & $-4,328$ & 0,000 \\
\hline 6 & mobility & 631,0 & 1906,0 & $-3,395$ & 0,001 \\
\hline 7 & informativeness & 773,5 & 2048,5 & $-2,255$ & 0,024 \\
\hline
\end{tabular}

\section{Conclusions}

1. The role of educational environment as a factor of personal education and development, which not only has to be taken into consideration in educational process but also has to be created, is emphasized. Based on existing approaches to interpreting the notions 'educational environment', 'educational environment of institution of higher education', it is determined that educational environment is a multilevel system of conditions / circumstances / factors / opportunities that provides optimal parameters of the educational activity of certain educational individual in all aspects - target, content, process, result, resource. The educational environment of a higher educational institution is an integrity that encompasses a set of conditions, impacts, opportunities for vocational training, personal development and socialization of the future specialist. The component structure and functions of the educational environment of the university college have been determined.

2. The author's technique of evaluating the state of 
educational environment of institution of higher education is suggested. It makes expert evaluation of educational environment of institution of higher education according to the qualitative (modality) and quantitative (professional breadth, professional saturation, sociocultural intensity, congruence, openness, mobility, informativeness) parameters. The typology of educational environment of institution of higher education (innovative-professional, formalprofessional, pragmatically-oriented, formal general cultural educational environment) is presented.

3 . The results of approbation of technique of evaluating the state of educational environment of institution of higher education by the example of educational environment of University College of Borys Grinchenko Kyiv University are presented. Reliability of obtained results is proved by means of Mann-Whitney U-test, Kolmogorov-Smirnov test, Friedman test. It is shown that expert groups consisting of students, teachers and students' parents evaluate educational environment, where the experiment took place, in a different way but their points are very similar.

Further research perspectives are connected with development of the integral system of monitoring educational environment of institution of higher education and corresponding diagnostic tools. In particular, research interest deals with development of criteria of evaluating the components of educational environment of institution of higher education.

The research was carried out within the framework of the complex scientific theme of the Department of Theory and History of Pedagogy of Borys Grinchenko Kyiv University "The content and technologies of ensuring the quality of life long pedagogical education in the context of European integration”), SR No 0116U003295.

\section{References}

1. N. Krylova, Antropologicheskiy, deyatelnostnyiy $i$ kulturologicheskiy podhodyi (Anthropological, activity and cultural studies approaches). (Scientific Research Institute of School Technologies, Moscow, 2005)

2. V. Kozyrev, Educator: Science, technology, practice 7, 26-32 (1999)

3. V. Yasvin, Obrazovatelnaya sreda: ot modelirovaniya $k$ proektirovaniyu (Educational environment: from modeling to design), 2nd edn. (Smyisl, Moscow, 2001)

4. S. Deryabo, Uchitelyu o diagnostike effektivnosti obrazovatelnoy sredyi (For teacher about the diagnosis of the effectiveness of the educational environment). (Molodaya gvardiya, Moscow, 1997)

5. V. Lebedeva, V. Orlov, V. Panov, in Abstracts of the 1rd Russian Conference on Environmental Psychology, Psychological Institute Russian Academy of Education, Moscow, 3-5 Dec. 1996

6. T. Warger, G. Dobbin, Learning Environments: Where Space, Technology, and Culture Converge (2009), https://aect.org/docs/ELI3021.pdf. Assessed 22 Oct 2019
7. B. Fraser, in Studies in educational learning environment: An international perspective, ed. by S.C. Goh, M.S. Khine (World Scientific Publishing, Singapore, 2002), pp. 1-25

8. V. Slobodchikov, The psychology of learning 1, 424 (2010)

9. M. Bratko, Higher education environment: functional aspect. Pedagogical process: theory and practice 1-2, 11-16 (2015)

10. J. Salmi, The Challenge Of Establishing WorldClass Universities (World Bank, Washington, 2009)

11. S. Cotterill, Capture 4, 47-54 (2013)

12. R. Hiemstra, Aspects of effective learning environments. New Directions For Adult And Continuing Education 50, 5-12 (1991). doi:10.1002/ace.36719915003

13. A. Lizzio, K. Wilson, R. Simons, University students' perceptions of the learning environment and academic outcomes: implications for theory and practice. Studies In Higher Education 27, 27-52 (2002). doi:10.1080/03075070120099359

14. I. Abualrub, B. Karseth, B. Stensaker, The various understandings of learning environment in higher education and its quality implications. Quality In Higher Education 19, 90-110 (2013). doi:10.1080/13538322.2013.772464

15. R. Moos, Evaluating educational environment: procedures, measures, findings and policy implications (Jossey-Bass, San Francisco, 1979)

16. V. Rubtsov, T. Ivoshina, Proektirovanie razvivayuschey obrazovatelnoy sredyi shkolyi (Designing the developing educational environment of the school). (Izd-vo MGPPU, Moscow, 2002)

17. V. Yasvin, S. Rybinskaya, Kompleksnaya otsenka obrazovatelnyih organizatsiy (Integrated assessment of educational organizations). (Izd-vo MGPPU, Moscow, 2015)

18. M. Bratko, Upravlinnia profesiinoiu pidhotovkoiu fakhivtsiv $v$ osvitnomu seredovyshchi universytetskoho koledzhu: teoriia $i$ praktyka (Management of Professional Training of Specialists in the Educational Environment of University College: Theory and Practice) (Axiom, KamianetsPodilskyi, 2017)

19. L. Vashchenko, Upravlinnia innovatsiinymy protsesamy $v$ zahalnii serednii osviti rehionu (Management of innovation processes in general secondary education of the region). (Tyrazh, Kyiv, 2005)

20. V. Yasvin, Research Educational Environment in Russian Psychology: from Methodological Discussion by the Empirical Results. Philosophy. Psychology. Pedagogy 18, 80-90 (2018). doi:10.18500/1819-7671-2018-18-1-80-90.

21. L. Panchenko, E. Adamenko, Kompyuternyiy analiz dannyih (Computer data analysis). (Publishing House of the State Institution of Taras Shevchenko State University, Lugansk, 2010) 